811.163.41'374

811.163.41'373

https://doi.org/10.18485/sj.2020.25.1.21

НАТАША М. МИЛАНОВ

Институт за српски језик САНУ

Београд
Оригинални научни рад

Примљен: 15. 10. 2019.

Прихваћен: 15. 01. 2020.

\title{
О КВАНТИТАТИВНИМ СВОЈСТВИМА ВЕЗАНИМ \\ ЗА ПОЛИСЕМИЈУ ЛЕКСЕМА У ТЕЗАУРУСНОМ РЕЧНИКУ СРПСКОГ ЈЕЗИКА**
}

Предмет рада је да се истражи удео лексема које имају изразито велики број значења у укупном фонду лексема забележених у највећем дескриптивном речнику српског језика, Речнику САНУ. Изузетно полисемичним сматраћемо оне лексеме које су у овом речнику реализовале најмање 15 значења или нијанси значења, те ћемо утврдити дистрибуцију овако издвојених лексема по објављеним томовима Речника. Циљ рада је да се на основу података о броју изузетно полисемичних лексема и њихових значења у највећем дескриптивном речнику српског језика допринесе осветљавању питања анализе квантитативих карактеристика лексичког система српског језика.

Кључне речи: квантитативна анализа, полисемија, моносемична лексема, Речник САНУ.

*natasa.milanov@isj.sanu.ac.rs

** Рад је настао у оквиру пројекта 178009 Лингвистичка истраживања савременог српског књижевног језика и израда Речника српскохрватског књижевног и народног језика САНУ, који у потпуности финансира Министарство просвете, науке и технолошког развоја Републике Србије. 


\section{1. УВОДНЕ НАПОМЕНЕ}

1.1. Квантитативна истраживања лексичког система на основу грађе из речника могу дати драгоцене податке о лексичком фонду једног језика и о његовој структури. ${ }^{1}$ Могућности оваквих истраживања су бројне - може се испитивати број значења која лексеме једног речника имају, тј. однос броја моносемичних лексема једног речника према броју лексема које имају више од једног значења, затим питање колико полисемичних лексема има два значења, колико њих пет значења, десет значења итд., колики је удео лексема које имају више значења у укупном фонду лексема забележених у једном речнику и др. Резултати истраживања зависе од обима речника̂ на којима се истраживање спроводи, па се подаци о броју лексема са одређеним бројем значења могу разликовати у речнику мањег обима од података које даје речник тезаурусног типа, али се на основу процената добијених оваквим испитивањем могу уочити тенденције у развоју језичког система, без обзира на обим испитиваног речника или начин узорковања грађе.

1.2. Као тезаурусни речник, Речник српскохрватског књижевног и народног језика САНУ (даље у тексту: Речник САНУ), тежи да попише целокупну лексику српског језика од почетка 19. века до савременог стања, и ону која припада стандардном језику, и ону која се употребљава у народним говорима на целом српском (новоштокавском) говорном подручју, због чега представља релевантан извор за различите врсте истраживања. Подаци добијени на основу изучавања квантитативних карактеристика лексема у речнику овог типа могу бити драгоцени за различита истраживања и у другим областима анализе лексичког система - морфологији, творби, семантици, дијалектологији, у испитивању нормативних карактеристика лексема итд.

\section{2. ЦИЉЕВИ И МЕТОДОЛОГИЈА ИСТРАЖИВАЬА}

2.1. Циљ овог рада јесте да се истражи удео лексема које имају велики број значења у укупном фонду лексема забележених у највећем дескриптивном речнику српског језика, Речнику САНУ. У раду ћемо се дотаћи и питања удела моносемичних лексема у одређеним томовима овог речника. Приказаћемо и дистрибуцију овако издвојених лексема по објављеним томовима Речника. На основу истраживања̂ сличног типа спроведених у другим језицима, стиче се

${ }^{1}$ Овај рад настао је на основу потпоглавља „О општим квантитативним карактеристикама лексема које имају велики број значења“, које је део докторске дисертације Полисемија српске лексике на корпусу Речника српскохрватског књижевног и народног језика САНУ, одбрањене 27. 9. 2017. на Филолошком факултету у Београду, пред комисијом коју су чиниле проф. др Рајна Драгићевић (ментор), проф. др Јелена Јовановић Симић и др Стана Ристић. 
увид да је удео изузетно полисемичних лексема у укупном лексичком фонду веома мали. Пошто ово истраживање спроводимо на незавршеном речнику, као и стога што се број лексема у језику процењује посредно преко речника, на основу добијених резултата пружићемо оквирну процену броја лексема које у српском језику имају веома богату полисемантичку структуру и тиме дати допринос осветљавању питања које се тиче анализе квантитативих карактеристика лексичког система српског језика, узимајући полисемичност лексема као критеријум анализе.

2.2. Најпре смо из досад објављених томова Речника САНУ (са граничним одредницама од $а$ до погдегод) издвојили лексеме које имају барем 15 значења или нијанси значења (у збир од 15 уврштена су значења (обележена бројевима) и подзначења (обележена словима)). На пример, значења именице ватра 1. а. „запаљена материја кад горећи развија топлоту и светлост, огањ”, б. „жеравица, жар”, в. „пламен”, рачунали смо као три значења. Приликом утврђивања броја значења лексема нисмо узимали у обзир именичке синтагме, пословице, фразеологизме и друге вишелексемске спојеве који се у Речнику САНУ обрађују у делу речничког чланка обележеном као Изр. (израз) и који тек у одговарајућим конструкцијама имају одређено, неретко специфично значење.

\section{3. ПРЕТХОДНА ИСТРАЖИВАЮА}

3.1. Утврђивање броја значења лексема за које се може рећи да су изузетно полисемичне, као и испитивање инвентара оваквих лексема вршена су на материјалу других језика. Њихова истраживања одговарају на три основна питања: колико значења мора имати лексема да би била изузетно полисемична, колики је удео изузетно полисемичних лексема у укупном фонду лексема забележених у речнику, као и какав је однос броја моносемичних и полисемичних лексема у речнику.

Таквом анализом бавили су се, између осталих, П. Н. Денисов (1984, 1993) и Ј. А. Чудинова (1998), на материјалу из речника руског језика, и И. Г. Ољшански (1991) на грађи из речника немачког језика. Издвојићемо овде запажање П. Н. Денисова о томе какве лексеме треба третирати као изузетно полисемичне. Наиме, овај аутор сматра да би као семантички најбогатије требало сматрати оне лексеме руског језика које у речнику имају седам или више нумерисаних значења, без подзначења, односно које су „реализоване у најмање осам различитих семантичких позиција" (Денисов 1984: 153). У српском језику, на грађи из прва три тома Речника САНУ, М. Дешић (1990: 3-9) испитивао је карактеристике изузетно полисемичних лексема. Овај аутор је изразито полисемичном сматрао лексеме које су реализовала најмање 15 значења (у овај број је урачунао и подзначења и изразе). 
Ми смо, узимајући у обзир ранија истраживања, као изузетно полисемичну третирали лексему која је реализовала најмање 15 значења (са подзначењима, без израза). Граница на седам, односно осам значења коју је навео П. Н. Денисов (1984: 153) нижа је од оне коју смо ми успоставили (15), али треба узети у обзир чињеницу да је овај аутор приликом препорука о броју значења изузетно полисемичних лексема у виду имао четворотомни речник руског књижевног језика (који се може поредити са шестотомним речником Матице српске ${ }^{2}$ ), те се стога за речнике већег обима ова граница мора померити навише.

3.2. За разлику од српске лингвистичке литературе, у иностраној литератури писало се и о томе који проценат лексема обрађених у речницима (који су најчешће различитог обима и неистоветне концепције) има више од једног значења. На пример, седмо издање речника енглеског језика Webster ${ }^{3}$, у коме су забележене 59.934 лексеме, садржи око 40\% лексема са два или више значења (Бирд и др. 1987: 226). У раду Бирда и др. (1987: 226) наводи се да се слични подаци могу дати за италијански језик, у коме, према неким истраживањима, $38,3 \%$ лексема има два или више значења. Затим, према речима Д. В. Качурина (2013), процењује се да је око $80 \%$ речи руског језика полисемично, али овај аутор сматра да се тај податак не може сматрати поузданим (2013: 91). У литератури налазимо и податак да у савременом немачком језику, према неким истраживањима, око $80 \%$ фонда чине вишезначне речи (в. Ољшански 1991: 15). Оваква истраживања би у српском језику требало спровести, али ће добијени резултати свакако зависити од врсте речника на коме се истраживање спроводи. На основу поменутих резултата можемо претпоставити да ће речник књижевног језика мањег обима имати процентуално мање моносемичних лексема, него речник тезаурусног типа који бележи и мање познату, застарелу, територијално нераспрострањену лексику, лексику која припада различитим терминолошким областима итд., а која често има свега једно значење.

3.3. Детаљним испитивањем квантитативних карактеристика лексема које имају велики број значења, на материјалу из речника руског језика, бавила се J. А. Чудинова (1998). Ова ауторка је приликом утврђивања квантитативних карактеристика полисемичних лексема у руском језику у другом издању четворотомног речника $\mathrm{MAC}^{4}$ издвојила 1.128 пунозначних полисемичних лексема са седам и више значења, што представља 1,35\% свих пунозначних речи у овом речнику (в. Чудинова 1998: 51). Она истиче да овај податак на први поглед показује да семантички најбогатије лексеме не представљају значајан

${ }^{2}$ Речник српскохрватскога књижевног језика, I-VI, Нови Сад (I-III и Загреб), Матица српска (I-III и Матица хрватска), 1967-1976.

${ }^{3}$ Webster's Seventh New Collegiate Dictionary, G. \& C. Merriam Company, Hardcover, 1963.

${ }^{4}$ Мальий академический словарь - Словарь русского языка в 4-х томах, Издание 1-е, 1957 1961; Издание 2-е, 1981-1984. 
удео у целокупној лексици, али да то не може представљати праву слику о укупном речничком фонду, већ је оквирни показатељ стања у језику. Такво истраживање реализовано је и на материјалу енглеског језика и закључено је да је у седмом издању речника енглеског језика Webster, ca осам и више значења 150 лексема, односно тек $0,25 \%$ свих лексема забележених у овом речнику (Бирд и др. 1987: 226). Наведене резултате упоредићемо са резултатима до којих смо ми дошли.

\section{4. О УДЕЛУ МОНОСЕМИЧНИХ ЛЕКСЕМА У ЛЕКСИЧКОМ ФОНДУ}

4.1. Тачан број моносемичних лексема у српском језику није познат, а за утврђивање ове карактеристике лексичког система као један од релевантних извора морају се узети речници. Како бисмо оквирно стекли увид у број моносемичних лексема у српском језику, као илустрацију смо прегледали три тома Речника CAHУ, IV, XV и XX том, дакле испитивање смо обавили на ограниченом узорку. Ове томове смо изабрали углавном због различите творбене структуре лексема које су у њима обрађене.

4.2.1. У IV тому Речника САНУ (Д-дугуља) лексикографски су, између осталих, обрађене и све лексеме творене префиксом до-. Од 13.973 обрађених лексема, око 80\% њих је према дефиницији моносемично. Морамо се запитати да ли овакав резултат има везе са творбеном структуром лексема које су у поменутом тому обрађене. Претпостављамо да има, и то потврђује закључак који се среће у литератури да префикси, у овом случају префикс $\partial o^{-5}$, најчешће сужавају семантику лексеме коју префиксирају. На пример, моносемичне су све лексеме које припадају творбеном гнезду полисемичног глагола касати, а које у творбеној структури имају префикс до- - докасати, докасавање, докасавати, докасивање, докасивати, докаскати, докаскивање, докаскивати . Међутим, овакав налаз на примеру лексема изведених префиксом до- ваљало би додатно проверити у будућим истраживањима и на широј грађи.

4.2.2. У XV тому (недотупав-нокавац) нашли смо да је од 9.499 забележених лексема такође око 80\% њих реализовало једно значење. Лексеме описане у овом тому углавном су непрефиксиране, изузев оних изведених префиксом не- који најчешће означава одрицање основне речи, њену супротност и сл. (в. Клајн 2002: 177). Овај префикс у највећем броју случајева твори лексеме које су према Речнику САНУ реализовале по једно значење (нпр. неаграрни, недавно, непаметно).

\footnotetext{
${ }^{5}$ О полисемичности префикса до- писала је Д. Гортан Премк (1997: 155).
} 
4.2.3. У XX тому (петогласник-погдегод) од 9.370 обрађених лексема једно значење има $76 \%$ од укупног броја лексема. У овом тому већина лексема је без префикса, а тек мали део обухвата лексеме изведене префиксом nо-. Запажамо да је и овде приближно исти број моносемичних лексема као и у два претходна тома.

4.3. Дакле, пребројавањем моносемичних лексема у поменутим томовима установили смо да је између $76 \%$ и $80 \%$ обрађених лексема моносемично, а да тек око једне петине од укупног броја пописаних лексема има бар два значења. Будући да је ово истраживање спроведено на свега три тома, добијени резултат представља оквирни показатељ семантичке структуре српске лексике.

4.4. Подаци о броју моносемичних лексема овог типа постоје за руски језик, али су неуједначени и разликују се од аутора до аутора. О томе извештава П. Н. Денисов (1993: 88) и каже да је према Ф. П. Фиљину око 66\% руских речи једнозначно. Са друге стране, С. Н. Муране је нашао да је моносемично $1,5-2 \%$ руских речи (од чега је $85 \%$ именица). Коментаришући велики раскорак у проценама ова два аутора, П. Н. Денисов наглашава да је у речнике руског језика укључен велики број једнозначних термина и закључује да је моносемичност концентрисана око специјалних професионалних и терминолошких изолованих сфера лексичког система језика (1993: 88). Како наводи А. Бежуан, мало лингвиста покушало је да процени квантитативна својства моносемичних лексема, да одговори на питање о томе колико речи се може сматрати моносемичним у енглеском и другим језицима, те да се добијени резултати разликују, а одступања, према овом аутору, вероватно настају „због неодређености дефиниције моносемије" (1998: 13).

4.5. Поменућемо још једно подстицајно истраживање које је за тему имало испитивање квантитативних својстава лексема у речнику. Према овом истраживању, зависност између обима речника и удела лексема са $x$ значења може се израчунати према формули, где у идеалном случају моносемичне лексеме заузимају половину корпуса лексема забележених у речнику, са два значења су лексеме које чине половину броја моносемичних, са три значења лексеме које чине половину броја лексема са два значења итд. (Пап 1967, према Ољшански 1991: 44). Међутим, показало се да се ова формула може применити на речнике малог и средњег обима (нав. дело). Биће веома корисно да се у будућим истраживањима провери важи ли ово правило и за српски језик, на основу грађе из речника мањег обима. Такође би било значајно испитати и колико значења полисемичних лексема припада општем лексичком фонду. Један од критеријума за такву анализу може бити и нормативна, терминолошка, стилска и др. квалификација полисемичних лексема и према томе испитивање удела ових лексема и њихових значења у речнику. 


\section{5. О УДЕЛУ ИЗУЗЕТНО ПОЛИСЕМИЧНИХ ЛЕКСЕМА У РЕЧНИКУ САНУ}

5.1. У српској лингвистичкој литератури налазимо податке о томе какве су лексеме склоне развитку великог броја значења. Полазећи од грађе из прва три тома Речника САНУ, на основу врсте речи којој припадају, етимологије, творбене структуре, као и примарног значења изузетно семантички богатих лексема, М. Дешић је закључио да највећи број значења имају речи домаћег порекла које припадају најужем језгру лексичког фонда - које су најфреквентније, а то је лексика која се односи на човека и његов живот, на животиње и биљке из човековог непосредног окружења, на делове његовог тела, предмете које свакодневно користи, радње које свакодневно обавља (Дешић 1990: 6). Ове лексеме, дакле, описују основне појмове, радње и појаве блиске човековом искуству. Међутим, квантитативни подаци о полисемичним лексемама досад нису били предмет темељнијег испитивања, те недостају прецизније информације о томе који је удео полисемичних лексема у укупном лексичком фонду српског језика на основу података из речника.

5.2. Шта је показало наше истраживање спроведено на свим досад објављеним томовима РСАНУ? Најпре, морамо напоменути да је до сада публиковано 20 томова Речника, а према најновијим проценама, када буде завршен, овај речник ће имати близу пола милиона речи и више од 30 томова. ${ }^{6}$ Речник САНУ за сада садржи укупно 241.257 одредница (в. Вуловић и др. 2019: 3). У литератури се наводи да први томови Речника САНУ имају у збиру више обрађених речи него новији томови. Овај податак има везе и са чињеницом на коју је указао Е. Фекете - да је у првим томовима разрада значења лексеме „мање изнијансирана, дефиниције су сажетије, а примери штедрије и концизније навођени" (1993: 43). Тада је, како наводи Фекете, планирано да речник има највише десет томова. Међутим, од тога се одустало, те се каснији томови „одликују већом разуђеношћу значењских нијанси речи, исцрпнијом семантичко-синтаксичком стилизацијом дефиниције, богатијом контекстуалном илустрацијом значења, знатнијом искоришћеношћу лексичке грађе и др." (Фекете 1997: 47). Важно запажање наводи и И. Грицкат која каже да је током рада на Речнику САНУ ,„растао смисао за разграничавање значењских нијанси" (Грицкат 1988: 39), те се повећавао прираштај значења код познатих речи - оно што је некад била померена, сликовита употреба речи, „данас се

${ }^{6}$ Поређења ради, процењује се да ће тезаурусни речник руског језика, Большой академический словарь русского языка, имати више од 150.000 обрађених одредница и око 30 томова (Кругликова 2012: 179). Са друге стране, у највећем дескриптивном речнику енглеског језика, Oxford English Dictionary, пописано је око 600.000 речи (према подацима са cajта http://www.oed.com/), са примерима употребе и од пре хиљаду година и из савременог доба, што овај речник чини и историјским. 
запажа као танана семантичка релеванција, као рођење и разлиставање нових значења" (нав. дело).

5.3. Међутим, осим концепције, и природа лексема мора имати утицаја на структуру тома. Речи које су у језику фреквентне и имају широку употребу, имају предиспозиције да буду и семантички богатије. О односу фреквенције лексеме и броја њених значења говори други Зипфов закон у коме се каже да је број значења једне речи једнак квадратном корену фреквенције њеног појављивања, а то значи да ће лексеме које имају највише значења бити и најфреквентније у корпусу (в. Јакић 2010: 504). Према Зипфу, у основи ових закона је принцип најмањег напора - за говорника је оптимално да кратка реч има што више значења (принцип унификације), а са друге стране за слушаоца да свако значење има посебну ознаку (принцип диверсификације). Како наводи М. Јакић, ове две тенденције заједно руководе променама у језику, а налази до којих је дошао Зипф у својим истраживањима ,унапредили су теорије учења страних језика и израду базичних речника, уводећи појмове као што је лексички минимум” (Јакић 2010: 504). Изузетно полисемичних лексема у језику нема много, али претпостављамо да би, узимајући у обзир други Зипфов закон, њихова фреквенција у тексту била висока, стога што већина таквих лексема спада у најуже језгро општег лексичког фонда. Особеност таквих лексема била би да су творбено немотивисане, словенског порекла, да имају богату полисемију и деривацију и да су фреквентне у савременом језику (в. Драгићевић 2018: 215).

5.4. Након издвајања лексема са најмање 15 значења и подзначења из досад објављених томова Речника САНУ установили смо да се за 887 лексема може рећи да су изузетно семантички богате. Представићемо њихову дистрибуцију по томовима Речника САНУ (в. Слику 1).

Слика 1. Однос броја полисемичних лексема по томовима Речника САНУ

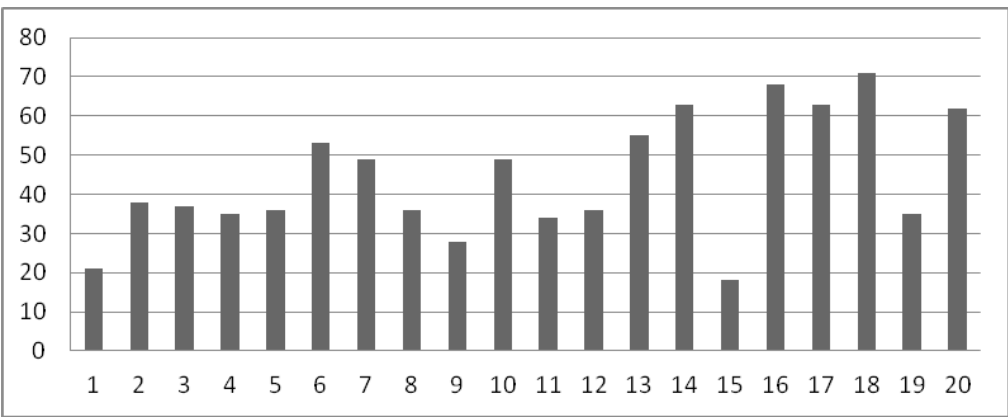


Из наведене слике запажамо да број лексема које су реализовале велики број значења варира од тома до тома Речника и креће се од око 20 (томови I и XV), па до преко 60 (томови XIV, XVI, XVII, XVIII и XX). Новији томови су богатији изузетно полисемичним лексемама. Поред промењеног начина обраде лексема, овакав резултат мора имати везе и са творбеном структуром лексема које се у одређеном тому обрађују. Такав закључак се намеће када се посматрају граничне одреднице томова и број изузетно полисемичних лексема које су у њима обрађене. Податке о томе даћемо у следећој табели (Табела 1).

Табела 1. Број полисемичних лексема по томовима Речника САНУ

\begin{tabular}{|l|c|}
\hline \multicolumn{1}{|c|}{ том } & бр. изузетно полисемичних лексема \\
\hline I (А-Богољуб) & 21 \\
\hline II (богољуб-Вражсогрнии) & 38 \\
\hline III (вразнути-гушчурина) & 37 \\
\hline IV (Д-дугуља) & 35 \\
\hline V (дугуљан-закључити) & 36 \\
\hline VI (закључница-земљен) & 53 \\
\hline VII (земљенаст-интонирање) & 49 \\
\hline VIII (интонирати-јурве) & 36 \\
\hline IX (јургет-колитва) & 28 \\
\hline X (колити-кукутица) & 49 \\
\hline XI (кукутка-маква) & 34 \\
\hline XII (маквен-мозурица) & 36 \\
\hline XIII (моире-наклапуша) & 55 \\
\hline XIV (накласати-недотруо) & 63 \\
\hline XV (недотупав-нокаваи) & 18 \\
\hline XVI (нокат-одврзивати) & 68 \\
\hline XVII (одвркао-Опово) & 63 \\
\hline XVIII (оповргавање-оиарити) & 71 \\
\hline XIX (оиат-петогласник) & 35 \\
\hline XX (петогодан-погдегод) & 62 \\
\hline Укупно & $\mathbf{8 8 7}$ \\
\hline
\end{tabular}


Табела показује да је највише лексема са великим бројем значења забележено у оним томовима који већим делом садрже лексику творену продуктивним префиксима за-, нa-, o-, oд-, по- (то су VI, XIII, XIV, XVI, XVII, XVIII и $\mathrm{XX}$ том). У вези с тим, навешћемо још једно запажање. У досадашњим истраживањима полисемије у српском језику која се ослањају на грађу из Речника САНУ (в. нпр. Дешић (1990), Гортан Премк (1997)), један од закључака јесте да су полисемији склоније просте речи него изведене, те да просте речи имају више значења него њихове изведенице. ${ }^{7}$ Насупрот поменутим закључцима, наша грађа је показала да већину изузетно полисемичних лексема чине изведенице, а доминантно место заузимају префиксирани глаголи (више о томе в. у Миланов 2017: 81-97). Будући да лексеме грађене неким од творбено продуктивних префикса тек чекају на лексикографско представљање и анализу (првенствено мислимо на лексеме творене префиксима no-, npe-, paз-, $c(a)$-), очекујемо да ће велики број полисемичних, пре свега глаголских лексема бити прикључен нашој бази изузетно полисемичних лексема.

5.5. Предмет нашег истраживања био је да утврдимо удео изузетно полисемичних лексема у укупном фонду лексема обрађених у Речнику САНУ. Издвојених 887 лексема чине тек $0,37 \%$ свих лексема које су описане у овом речнику. Овај податак говори да је проценат изузетно полисемичних лексема у укупном броју лексема у Речнику САНУ занемарљив, те се стога може рећи да се овај налаз уклапа у налазе других аутора који су се бавили овим питањем, о томе да је укупан број лексема у неком речнику обрнуто сразмеран броју лексема које имају велики број значења. Овакав закључак поткрепљује и констатација коју је изнео И. Ољшански - што је већи обим речника, то је у њему мањи удео изузетно полисемичних лексема (Ољшански 1991: 7). Такав налаз је и очекиван будући да ће велики дескриптивни речници који теже да попишу целокупни лексички фонд једног језика садржати и лексеме које се ретко употребљавају или се употребљавају на малом географском простору, чије се постојање, значење и употреба једино ту могу посведочити.

5.6. Ако сагледамо број изузетно полисемичних лексема у досадашњим томовима у односу на пројектовани број лексема којих ће, према проценама, бити око 500.000, као и творбену структуру лексема које тек чекају обраду, можемо оквирно претпоставити да ће се у Речнику САНУ, када он буде завршен, наћи око 1.500 изузетно полисемичних лексема са најмање 15 значења. Међу тим лексемама већина ће, претпостављамо, чинити језгро лексичког система

${ }^{7}$ У вези са овим навешћемо и запажање А. Визентал (2009: 41) која каже да је већина енглеских речи, посебно оних германског порекла, врло једноставне форме (једносложне су или двосложне), али су семантички комплексне. А. Бежуан износи констатацију да моносемичне речи имају тенденцију да буду дугачке и ретке употребе, док фреквентне речи теже да буду кратке и полисемичне (1998: 20). 
српског језика (то су оне речи које описују основне појмове, радње и појаве блиске човековом искуству) (уп. Миланов 2017: 501-512).

5.7. Видели смо да у различитим језицима постоји тенденција да лексеме са великим бројем значења имају незнатан удео у укупном фонду лексема обрађених у речнику. Представићемо графички тај однос на примеру Речника САНУ, речника руског језика МАС и речника енглеског језика Webster (в. Слику 2).

\section{Слика 2. Прочентуални однос укупног броја обрађених лексема и броја} изузетно полисемичних лексема у речницима (удео изразито полисемичних лексема - РСАНУ 0,37\%, MAC 1,25\%, Webster 0,25\%)

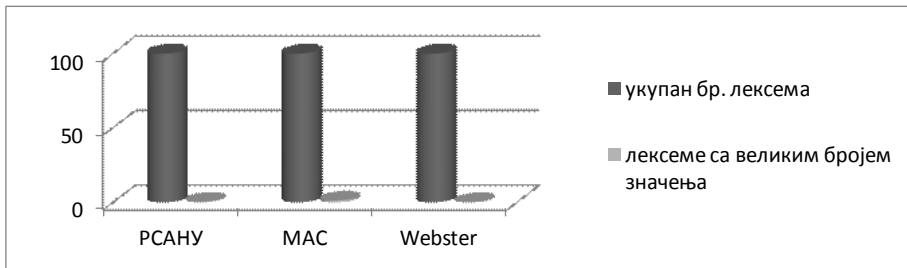

Иако су речници чије смо податке упоређивали различитог обима и са различитим начином утврђивања броја значења изузетно полисемичних лексема, ипак се може уочити, ако се однос броја значења изрази у процентима, да је веома мало лексема које имају велики број значења у односу на укупан број забележених лексема.

5.8. Ваља још једном истаћи да се подаци до којих смо дошли прегледом томова Речника САНУ не могу узимати као прецизни показатељ реалне ситуације у језику већ као нека врста тенденције стања лексикона, на основу података из дескриптивног речника. И поред тога што се добијени резултати морају узети са резервом, на основу досад публикованих томова можемо стећи увид у инвентар и семантичку структуру лексема са великим бројем значења.

\section{6. ЗАКЉУЧАК}

У истраживању бавили смо се анализом квантитативних својстава лексема које имају велики број значења - најпре нас је занимао однос броја моносемичних и полисемичних лексема у речнику, затим питање колико значења мора имати лексема да би била изузетно полисемична, те колики је удео овако издвојених лексема у укупном фонду лексема забележених у речнику. С циљем да оквирно утврдимо број моносемичних лексема, прегледали смо три одабра- 
на тома Речника CAHУ (IV, XV и XX) и установили да је, према подацима које дају ови томови, велика већина лексема у српском језику моносемична. Овај налаз очекиван је с обзиром на то да речник тезаурусног типа бележи и мање познату, застарелу, територијално нераспрострањену лексику, лексику која припада различитим терминолошким областима итд., а која често има свега једно значење. Даље, анализа је показала да је тек око $0,4 \%$ лексема у српском језику изразито полисемично (то су лексеме које имају барем 15 значења или подзначења), као и да број оваквих лексема варира од тома до тома речника. Овакво стање свакако има везе и са творбеном структуром лексема које се у одређеном тому обрађују. Већи број изразито полисемичних лексема садрже томови у којима је пописана лексика творена продуктивним префиксима за-, $н a-, o-, o \partial-$, nо-. Значајни за поређење били су и подаци о квантитативним карактеристикама лексикона у другим језицима, на основу података из речника. Утврдили смо да се и у другим језицима (руском, енглеском) наилази на слично стање када је у питању број изузетно полисемичних лексема, те се као универзалан може изнети налаз да је удео лексема са великим бројем значења у тезаурусним речницима изразито мали. Квантитативна истраживања лексичког система на материјалу дескриптивних речника могу помоћи у разумевању функционисања лексикона једног језика, у утврђивању начина на који се богати лексички фонд, а посредством језика, између осталог, дознаје се и које су области стварности човеку најважније.

\section{ЛИТЕРАТУРА}

Бежуан 1988: H. Béjoint, Monosemy and the dictionary, BUDALEX88 PROCEEDINGS from the EURALEX Third International Congress, 13-26.

Бирд и др. 1987: R. J. Byrd, N. Calzolari, M. S. Chodorow, J. L. Klavans, M. S. Neff, O. A. Rizk, Tools and methods for computational lexicology, Computational Linguistics 13 (3-4), 219-240.

Визентал 2009: A. Vizental, Meaning and Communication From Semantic Meaning to Pragmatic Meaning, Arad: Editura Universității Aurel Vlaicu.

Вуловић и др. 2019: Н. Вуловић, М. Ђинђић, Д. Радоњић, У другој половини Речника САНУ. Двадесет томова српског тезауруса, Наш језик XLIX/2, 115-119.

Гортан Премк 1997: Д. Гортан-Премк, Полисемија и организащија лексичког система у српскоме језику, Београд: Институт за српски језик CAHУ. 
Грицкат 1988: И. Грицкат, Речник Српске академије наука и уметности - почеци, лик, перспективе, Глас CCCLII Српске академије наука и уметности, Одељење језика и књижевности, књ. 13, 25-40.

Денисов 1984: П. Н. Денисов, Место и роль самых многозначных слов в лексической системе языка, Слово в грамматической системе языка, 142-158.

Денисов 1993: П. Н. Денисов, Лексика русского языка и принципь её описания, Москва: Русский язык.

Дешић 1990: M. Dešić, Iz srpskohrvatske leksike, Nikšić: Univerzitetska riječ.

Драгићевић 2018: Р. Драгићевић, Српска лексика у прошлости и данас, Нови Сад: Матица српска.

Јакић 2010: М. Јакић, Значај фреквенције употребе језичких јединица у лингвистичким истраживањима, Српски језик XV, 2010, 501-514.

Качурин 2013: Д. В. Качурин, Проблема разграничения омонимии и полисемии применительно к практике составления толковых словарей, диссертация, Москва.

Клајн 2002: И. Клајн, Творба речи у савременом српском језику, Први део, Слагање и префиксација, Београд: Завод за уџбенике и наставна средства, Институт за српски језик САНУ - Нови Сад: Матица српска.

Кругликова 2012: Л. Е. Кругликова, Большой академический словарь русского языка как продолжатель традиций русской академической лексикографии, Cuadernos de Rusística Española, 8, 177-198.

Миланов 2017: Н. Миланов, Полисемија српске лексике на корпусу Речника српскохрватског књижевног и народног језика САНУ, необјављена докторска дисертација, Београд.

Ољшански 1991: И. Г. Ольшанский, Лексическая полисемия в современном немецком языке, автореферат диссертации, Москва.

Речник САНУ: Речник српскохрватског књижевног и народног језика, I-XX, Београд: Српска академија наука и уметности - Институт за српскохрватски/српски језик, 1959-.

Фекете 1993: Е. Фекете, О Речнику српскохрватског књижевног и народног језика САНУ, Сто година лексикографског рада у САНУ, Београд, 21-49.

Фекете 1997: Е. Фекете, Поводом петнаестог тома Речника САНУ, Наш језик XXXII/1-2, 45-51. 
Чудинова 1998: Е. А. Чудинова, Широко развитая многозначность в лексике современного русского языка (по материалам лексикографии), диссертация, Екатеринбург.

\section{THE QUANTITATIVE PROPERTIES OF POLYSEMIC LEXEMES IN THE THESAURUS DICTIONARY OF SERBIAN LANGUAGE}

\section{Summary}

In this paper, we examined the quantitative characteristics of lexemes in the largest descriptive dictionary of the Serbian language, The Dictionary of the Serbian Academy. As extremely polysemic we considered lexemes that realized at least 15 meanings (primary and secondary). In order to estimate the number of monosemic lexemes, we examined three selected volumes of The Dictionary of the Serbian Academy (IV, XV and XX) and found that the vast majority of lexemes in the Serbian language are monosemic. Furthermore, the analysis showed that only about $0.4 \%$ of Serbian lexemes are highly polysemic. One of our tasks was to determine the distribution of such lexemes according to the published volumes of the Dictionary. It has been shown that it varies in different dictionary volumes, but also that the result has to do with the structure of the lexemes that are processed in a given volume. A large number of highly polysemic lexemes are contained in volumes in which the lexemes are formed by the productive prefixes $z a-, n a-, o-, o d-, p o-$. Also, we have found that, when it comes to the number of extremely polysemic lexemes, there's a similar condition in other languages.

Keywords: quantitative analysis, polysemy, monosemic lexeme, Dictionary of the Serbian Academy. 